(afterwards Sir James) Dewar. This was the beginning of another long tenure, for Dewar held the professorship for forty-six years, until his death in 1923 ; and from 1887, after Tyndall's retirement, he lived at the Institution as the resident professor.

Dewar's matchless skill as an experimenter, the fame of his researches, and of his Friday evening lectures with their carefully prepared and rehearsed demonstrations, are well known and remembered. In the Royal Institution laboratories, with apparatus often on an engineering scale, he liquefied the so-called permanent gases, and produced them for the first time-oxygen, hydrogen and air-in quantities sufficient for experiments on the properties of materials at the very low temperatures he reached; he invented, as a container for the cooled gases, the 'thermos' or Dewar flask; and he developed the method, of great technical importance, of making high vacua by using the great absorbing power for gases of charcoal cooled in liquid air. These are but the best known among his achievements. To quote the words of a distinguished contemporary : "He was . . . in no way less successful than his predecessors,
Young, Davy and Faraday, in adding to the reputation these pioneers created for the Royal Institution as a centre of scientific discovery and invention". It may be added that the recent lamented death of Lady Dewar is a reminder that not the least important of the Dewars' services to science was given as host and hostess in their house at the Institution.

Since Tyndall, three physicists of great distinction have held the professorship of natural philosophy who have also been, in turn, the Cavendish professor of physics at Cambridge. The late Lord Rayleigh, soon after his retirement from Cambridge, accepted the invitation to the chair at the Royal Institution, and held it until 1905 ; when he was succeeded by Sir J. J. Thomson. The present professor, Lord Rutherford, took up the duties in 1921. The rules prescribed at the beginning of the Institution for the election of professors are still followed; and thus it is that Lord Rutherford, as an 'elected' professor, must seek the suffrages of the members once a year, while Dewar's successor in the endowed Fullerian professorship of chemistry, the present resident professor, Sir William Bragg, does not do so.

\title{
Obituary
}

Mr. C. F. Cross, F.R.s.

$\mathrm{M}$ R. Charles Frederick Cross, who died in his eightieth year on April 15 at Hove, where he had lived in retirement for some years, left us indebted to him for a life devoted to a most difficult and unpromising branch of chemical research, rewarded by an epoch-making discovery, which is represented in Great Britain to-day by an artificial silk industry with a market capitalisation of more than $\mathfrak{f} 70,000,000$. $\mathrm{He}$ was educated at King's College, London, the University of Zurich and Owens College, Manchester. In 1879 , his work on the cellulose group commenced with a study of jute, and later, in association with Mr. E. J. Bevan and Mr. C. Beadle, he started the well-known business of Cross and Bevan, consultants to the paper trade.

It is difficult to estimate the number of papers on the chemistry of cellulose published by Cross and his collaborators; these date from 1880 until 1920, and appeared in the Journal of the Chemical Society, Journal of the Society of Dyers and Colourists, Berichte, Phil. Mag., Bull. Soc. Chim., and many lessknown publications. In these and in his textbooks, he has left us a mine of information and, as Prof. H. E. Armstrong has pointed out, the mystic character of some of his explanations must be ascribed to the intangible nature of his subject. Fulfilling the functions that it does in the plant, cellulose is on the border-line of living substances itself, and is liable to alter with every change in conditions to which it is subjected. His suggestion that it is an 'amphoteric electrolyte' hides a complexity of behaviour that has not been much illuminated by more modern advances in chemical language.

In 1892, Cross discovered that, by virtue of the alcoholic properties of cellulose, a soluble xanthate could be obtained on reaction with caustic soda and carbon disulphide. Working at Kew with Stearn and Topham, who were at first interested in the application of the new discovery to the manufacture of electric lamp filaments, the practical difficultios in spinning a continuous textile fibre were overcome, and the viscose silk industry was born.

At first, the solution of cellulose xanthate was expressed through a number of fine holes into a solution of ammonium sulphate, and the use of an acid bath, which resulted in the formation of a cellulose thread in one operation, was not arrived at until years later. The reception of the thread in a centrifugal box, which collected, drained and twisted it in one operation, due to Topham, has remained the standard practice up to the present day. In 1905, manufacture was started by the firm of Courtauld at Coventry, and the writer, then in charge of the chemical department, has a lively recollection of Cross, who took a great interest in the new venture, with his interesting suggestions, cheery sporting manner, wide culture and artistic interests.

Recognition of the value of Cross's work came later ; in 1917 he was elected fellow of the Royal Society, in 1916 he received the medal of the Society of 
Chemical Industry and in 1918 the research medal of the Worshipful Company of Dyers. He was elected president of the Society of Dyers and Colourists in 1918, and received the Perkin Medal in 1923. SIDNEY S. NAPPER.

Colonel W. G. King, c.I.e.

Colonel Walter Gawen KIng, late of the Indian Medical Service, died at his home at Hendon on April 4 at the age of eighty-three years. He graduated M.B. and C.M. in 1873 at the University of Aberdeen, where he also took the D.P.H. in 1888. Soon after qualifying, and before his twenty-third birthday, he entered the Indian Medical Service, in which he passed the next thirtysix years of his life.

On reaching India in 1874 , King was posted to the Madras Presidency and, after two years military service with an Indian regiment, was transferred to civil employment, in which he quickly distinguished himself for his active work in the great famine of 1876-77 and the terribly severe cholera epidemic which accompanied it. This experience made him decide to devote his life to preventive medicine, and it is chiefly for the remarkable work which he did in this sphere during a succession of appointments as inspector of vaccination, deputy sanitary com. missioner and sanitary commissioner of the Madras Presidency and later as inspector general of civil hospitals and sanitary commissioner of Burma, that his name will go down to posterity as the leading pioneer of public health in southern India.

King's great merit was that at a time when smallpox, cholera and malaria were the three chief scourges of India, and when the scientific world knew nothing of the causes of cholera or malaria, and, therefore, knew nothing of their prevention, he set to work to organise scientific investigations for the benefit of public health and did not pause in the task until the goal he aimed at was attained. At that time, bacteriology was in its youth and the modern sciences of tropical protozoology, helminthology and medical entomology were in their earliest infancy or were as yet unborn. The malaria parasite was not discovered until 1881, and the fact that it is spread by mosquitoes not until 1897. The cholera vibrio was not discovered until 1883. Smallpox, however, could be controlled because a prophylactic was already available and the only problem to be solved was how best it could be applied. In Madras, vaccination with animal lymph instead of with human lymph was successfully established in 1880-81, but more than ten years were to elapse before a satisfactory method of preserving the lymph under tropical conditions was devised. King's well-planned and carefully controlled laboratory experiments conducted in 1890 to ascertain the relative merits of lanoline and vaseline as a preserving medium may be cited as a good example of the immediate utilitarian researches to which he devoted what time he could spare from his many other duties.

Later when, at his repeated request, the Govern. ment of Madras established a central animal vaccine lymph depot for the Presidency, King quickly extended its work to include bacteriological diagnosis and other expert assistance to civil surgeons and medical practitioners, and finally made arrangements for the preparation of prophylactic and curative sera and vaccines and for the prosecution of original protozoological and entomological research of direct importance to tropical medicine. In 1903, when the main buildings of the bacteriological section were completed, the Institute became the provincial laboratory for the Madras Presidency and was named, in recognition of King's services to public health and the efforts he had made to bring it into existence, "The King Institute of Preventive Medicine". In the general scheme for laboratories which had been submitted to the Government of India by the late Surgeon-General Harvey in 1899 it was the third to be established, being preceded only by the Haffkine Institute at Parel, Bombay (1896-99), and the Pasteur Institute of India at Kasauli (1900).

After his retirement, Colonel King served in the War from 1916 as A.D.M.S. Western Command and later was consultant at the Tropical Diseases Clinic, Ministry of Pensions, and lecturer in applied hygiene in the tropics at King's College, London. He had the satisfaction, too, of seeing the institute in India which he founded grow gradually until its activities covered a wider field in the practical application of scientific knowledge to routine medical and public health needs than those of any other laboratory in India.

S. P. J.

\section{Prof. R. Carr Bosanquet}

WE regret to record the death of Prof. R. Carr Bosanquet, formerly professor of classical archæology in the University of Liverpool, which took place on April 21 in a nursing home at Newcastle at the age of sixty-three years.

Robert Carr Bosanquet was the son of Mr. Charles Bertie Pulleine Bosanquet, and was born at Rock Hall, near Alnwick, on June 7, 1871. He was educated at Eton, where he was Newcastle Scholar in 1890 and edited the Eton College Chronicle, and at Trinity College, Cambridge, of which foundation he was a scholar. He took firsts in both parts of the Classical Tripos, and was elected to a Craven travelling studentship, which he held from 1895 until 1897.

Bosanquet's interest in archæology was first aroused by the antiquities of Roman Britain which lay within striking distance of his home. In 1897 he excavated Housesteads (Borcovicium) on the Roman Wall. In the following year he was appointed assistant director of the British School of Archæology in Athens, later succeeding to the office of director. In 1906 he was elected to the chair of classical archæology in the University of Liverpool, which he occupied until 1920, when he retired in order to devote himself to the management of the estate which he had inherited from his father, giving such time as this allowed him to further research in the archæology of Roman Britain. He was a member of the Royal Commission on Ancient Monuments in Wales, a position for which his extensive knowledge 